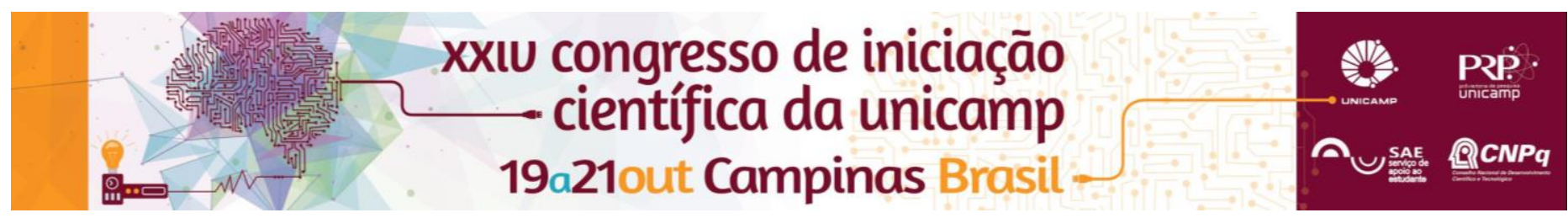

\title{
Novas iniciativas na educação formal - Análise de três protótipos feitos para o Projeto "Escolas de Ensino Integral" da SEE-SP
}

\section{Cauê Félix e Silva*}

\begin{abstract}
Resumo
No projeto, foram feitas as análises críticasde três protótipos didáticos, realizados pelo autor da pesquisa, para o projeto "Escolas de Ensino Integral" da SEE-SP, tendo como base estudo teórico acerca de temáticas envolvendo novas tecnologias e suas aplicações no ambiente escolar e a pedagogia dos multiletramentos. Também foram comentados a evolução e necessidade de mudanças nos materiais didáticos, além de críticas às políticas públicas acerca deste projeto da Secretaria de Educação paulista.
\end{abstract}

\section{Palavras-chave:}

Multiletramentos, Novos letramentos, Protótipos didáticos,.

\begin{abstract}
Introdução
A transformação da forma em que a sociedade contemporânea se comunica é inegável devido ao desenvolvimento acelerado de tecnologias digitais nessa área. Consequentemente, as alterações de formas de lidar na comunicação interpessoal passa a influenciar outros espaços, como o da Educação.

Neste contexto, o Grupo de Nova Londres criou a Pedagogia dos Multiletramentos, a qual é composta por dois conceitos essenciais que embasaram os protótipos que foram realizados no projeto feito para a Secretaria da Educação: o multiliguismo e a multimodalidade. O primeiro refere-se às variações da língua de determinada localidade, reconhecendo-se para além da forma padrão da língua. Já a multimodalidade refere-se à multiplicidade textual (desenhos, sonoros, imagens estáticas e em movimento, verbais escritos etc.) e suas integrações na atualidade.

Baseados nessas transformações, os materiais didáticos escolares também sofreram alterações, sendo criado o formato de Protótipos Didáticos, os quais foram desenvolvidos para um projeto de período integral nas escolas públicas estaduais de São Paulo, outra discussão que ganhou força nos últimos anos. Deste modo, o objetivo da pesquisa é analisar criticamente os protótipos que foram desenvolvidos neste projeto.
\end{abstract}

\section{Resultados e Discussão}

Esta pesquisa proporcionou um período para observar mais criticamente o material que foi produzido no início de 2015

O maior embasamento teórico traz outros olhos sobre o material. E deste modo, a primeira consideração que pude fazer sobre os Protótipos Didáticos produzidos é: Estes não se encaixam bem na definição de Protótipos Didáticos, se aproximando mais de Sequências Didáticas.

Apesar da possibilidade de substituir os textos de cada material desenvolvido e "encarnar" o "esqueleto", a maioria das atividades desenvolvidas já foram pensadas com base na coleção textual escolhida.

Dos Protótipos em si, foram analisadas as versões desenvolvidas para os professores, a qual engloba a versão do aluno, acrescentada de comentários e indicações de respostas e resoluções para as atividades propostas.

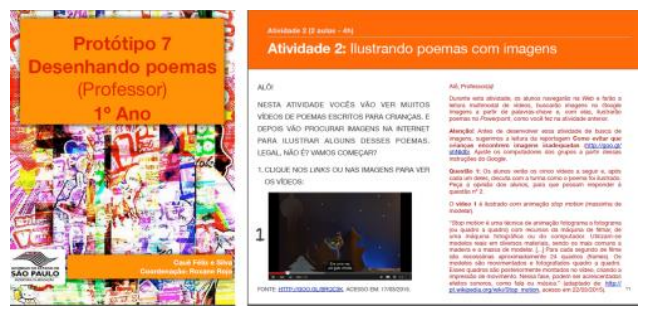

Figura 1. Protótipo 7 - Desenhando Poemas

$\mathrm{Na}$ análise feita, foi possível perceber que os "esqueletos" dos Protótipos propiciam grande integração entre textos complementares de diversas modalidades, tornando-se um material multimodal, o qual estimula capacidades como pesquisar digitalmente de forma segura e confiável, indexar textos, interagir por meio de diversas redes sociais específicas pra diversas modalidades textuais etc. O conteúdo que foi utilizado nos protótipos foi todo baseado em atividades do material didático "Ler e Escrever", aplicado pela SEE-SP nas escolas estaduais do estado paulista, deste modo ele fica marcado por um espaço-tempo, mesmo tendo sido pensado para se descolar dessas amarras.

Desta forma, apesar do material produzido para este projeto da SEE-SP ser muito coerente com as teorias que dos novos e multiletramentos e desdobramentos sociais trazidos por essas práticas, apenas saberemos sua eficácia quando for aplicado no ambiente escola.

\section{Conclusões}

Os Protótipos Didáticos são uma ótima alternativa para o desenvolvimento desses materiais, levando em conta o dinamismo proporcionado pelo avanço das TDICs. A escola não se dar no ambiente digital passa a não fazer mais sentido em alguns espaços, como grandes centros urbanos muito conectados. Deste modo, o desenvolvimento e o olhar crítico sobre os novos materiais didáticos possibilitam cada vez mais a integração do estudo escolar do aluno, com sua vida conectada externa à escola.

\section{Agradecimentos}

Agradeço primeiramente à minha orientadora, Prof. Dr. Roxane H. R. Rojo, por ser uma grande pessoa, professora e amiga. Agradeço a Universidade Estadual de Campinas e ao CNPq por viabilizar a realização desta pesquisa. 